\title{
Political Communications of The Ministry of Education and Culture about "Merdeka Belajar, Kampus Merdeka (Independent Learning, Independent Campus)" Policy: Effective?
}

\author{
Era Purike
}

Politeknik Pajajaran ICB Bandung, Indonesia

\begin{abstract}
The policy of the Ministry of Education and Culture (Kemdikbud) regarding "Merdeka Belajar, Kampus Merdeka (Free Learning, Independent Campus) as outlined in 5 (five) policies (Permendikbud) as a legal umbrella for this policy. This policy was launched on January 24, 2020 and is a breakthrough made by the Ministry of Education and Culture in the education sector in Indonesia. As a new policy, this policy is likely to experience obstacles, especially in its implementation. Therefore, effective communication is needed to achieve the objectives (outputs) of this policy. This research was conducted through literature review and monitoring of official online media as tools used by the Ministry of Education and Culture to socialize this policy. Policy communication could be effective if: (1) the policy can be received and understood as intended by the government; (2) the policy launched by the government can be approved by the recipient and followed up with the proper implementation as required by the government; (3) there are no significant obstacles to follow up and implement the policy. The results of this study indicate that there are still misinterpretations regarding the contents of this policy. The results of literature review state that educational institutions are still having difficulty implementing this policy in curriculum adjustments and learning activities. They also have obstacles to follow up on links and match programs for independent learning with industry due to it requires much budget and many universities have low budget.
\end{abstract}

Keywords: Communication; policy implementation; new policies; education.

\section{Introduction}

Perubahan global yang terjadi saat ini terutama di bidang teknologi memberikan dampak pada perubahan sosial di masyarakat terutama masyarakat Indonesia. Pergeseran pola komunikasi yang biasanya dilakukan secara langsung, telah digantikan menjadi pola komunikasi menggunakan media. Teknologi komunikasi yang berkembang sangat pesat pada saat ini merupakan sebuah kemajuan budaya yang bersifat massal. Hal ini juga berdampak pada perubahan dalam banyak aspek kehidupan masyarakat, baik masyarakat di perkotaan maupun masyarakat yang berada jauh dari pusat-pusat pemerintahan. Teknologi komunikasi menjadi sebuah kebutuhan vital bagi kehidupan masyarakat ( $\mathrm{S}$, 2018).

Perkembangan teknologi ini menuntut adanya perubahan keterampilan pada manusia sebagai bentuk coping strategy atau bentuk adapatasi untuk keberlangsungan hidup manusia itu sendiri. Manusia harus mampu memberikan respon terhadap perkembangan ini dan beradaptasi secara cepat terhadap tuntutan perkmbangan teknologi informasi. Maraknya penggunaan teknologi 4.0 bahkan 5.0 membuat manusia harus mampu meningkatkan keterampilan, kreativitas, dan inovasi yang dapat mendukung perkembangan teknologi yang ada. Demikian juga halnya dengan tuntutan dunia industri yang membutuhkan Sumber Daya Manusia (SDM) yang mampu menjawab tantangan teknologi 4.0 dan 5.0 ini. Peningkatan kapabilitas SDM ini dapat dilakukan dengan adanya perubahan paradigma

\footnotetext{
* Corresponding author.

E-mail address: era.purike@ poljan.ac.id (Era Purike)
} 
dalam pendidikan sehingga dapat melahirkan generasi-generasi baru yang siap menjawab tantangan perkembangan teknologi informasi yang sangat pesat.

Hal inilah yang menjadi latar belakang diberlakukannya kebijakan "Merdeka Belajar dan Kampus Merdeka". Sebagaimana dilansir di halaman situs resmi Kementerian Pendidikan dan Kebudayaan (Kemdikbud) https://kemdikbud.go.id bahwa kebijakan ini merupakan kebijakan yang bertujuan mendorong mahasiswa untuk menguasai berbagai keilmuan yang berguna untuk memasuki dunia kerja. Kampus Merdeka memberikan kesempatan bagi mahasiswa untuk memilih mata kuliah yang akan mereka ambil. Adapun payung hukum dari kebijakan Merdeka Belajar, Kampus Merdeka dituangkan dalam 5 kebijakan yaitu Permendikbud No. 3 Tahun 2020 tentang Standar Nasional Pendidikan Tinggi, Permendikbud No. 4 Tahun 2020 tentang Perubahan Perguruan Tinggi Negeri menjadi Perguruan Tinggi Badan Hukum, Permendikbud No. 5 tahun 2020 tentang Akreditasi Program Studi dan Perguruan Tinggi, Permendikbud No.6 tahun 2020 tentang Penerimaan Mahasiswa Baru Program Sarjana pada Perguruan Tingggi Negeri dan Permendikbud No. 7 tentang Pendirian, Perubahan, Pembubaran Perguruan Tinggi Negeri dan Pendirian, Perubahan dan Pencabutan Izin Perguruan Tinggi Swasta.

Kebijakan ini merupakan sebuah terobosan kebijakan baru dalam bidang Pendidikan di Indonesia. Ada beberapa tipe kebijakan yang menurut Winarno (2012) mempunyai potensi untuk menimbulkan masalah, yakni kebijakan baru, kebijakan yang didesentralisasikan, kebijakan kontroversial, kebijakan yang kompleks, kebijakan yang berhubungan dengan krisis, dan kebijakan yang ditetapkan oleh pengadilan. Dalam hal kebijakan itu merupakan sebuah kebijakan baru, maka sifat kebaruan tersebut membuat kebijakan cenderung sukar dilaksanakan. Beberapa alasan yang memperkuat hal ini, antara lain: tujuan-tujuan yang ditetapkan seringkali tidak jelas; program-program baru mungkin menghadapi kelangkaan sumber daya seperti minimnya informasi, staf yang tidak memadai, dan kurangnya personil yang terampil; jika program baru tidak konsisten dengan misi utama badan pelaksana, mungkin program tersebut akan mendapat prioritas dan sumber daya yang rendah dari para pelaksana; seringkali program baru dilaksanakan secara tidak konsisten dan dilakukan dengan cara-cara yang sudah lazim; para pelaksana mengubah kebijakan baru untuk disesuaikan dengan SOP lama yang tidak tepat. Berdasarkan hal tersebut, maka Kemdikbud sebagai pencetus kebijakan harus memiliki komunikasi yang efektif agar informasi dapat disosialisasikan secara luas. Diharapkan dengan efektifnya komunikasi ini, kebijakan dapat diimplementasikan dengan tepat sesuai dengan tujuan kebijakan yang telah ditetapkan.

Tujuan utama komunikasi politik adalah penggunaan saluran media untuk mengkomunikasikan pandangan, solusi, dan interpretasi politik tertentu dari suatu masalah dengan harapan mendapatkan dukungan publik atas kebijakan politik tertentu (Romy Froehlich, 2006). Komunikasi diperlukan agar tujuan atau output dari sebuah kebijakan sesuai dengan tujuan atau output yang sudah ditetapkan dalam kebijakan yang dikeluarkan.

Penelitian ini bertujuan untuk melihat efektivitas komunikasi yang dilakukan oleh Kemdikbud terhadap kebijakan "Merdeka Belajar Kampus Merdeka". Kebijakan ini menekankan pada pembelajaran yang berpusat pada peserta didik (Students Centered Learning/SCL). Pendekatan SCL membutuhkan keaktifan dari para peserta didik sehingga mereka dapat lebih luas mengembangkan wawasannya dan mengembangkan pola pikir baru yang dapat menjawab tantangan yang dihadapi serta mampu mengembangkan kreatifitas dan inovasi di berbagai aspek kehidupan (Syamsul Arifin, 2020). Oleh karenanya, pendekatan SCL membutuhkan tenaga pengajar yang mampu berperan bukan hanya sebagai pengajar tapi juga berfungsi sebagai motivator, fasilitator, dan innovator (Antika, 2014).

Berdasarkan data tahun 2017 dari Kementerian Riset Teknologi dan Perguruan Tinggi (saat ini menjadi Kementerian Pendidikan dan Kebudayaan), jumlah unit perguruan tinggi yang terdaftar mencapai 4.504 unit. Perguruan Tinggi Swasta (PTS) merupakan jumlah terbanyak, yaitu 3.136 unit. Sedangkan Perguruan Tinggi Negeri (PTN) justru paling sedikit jumlahnya, hanya 122 unit. Sisanya merupakan perguruan tinggi agama dan perguruan tinggi dibawah kementerian atau Lembaga negara dengan system kedinasan. Namun, banyaknya jumlah PTS ini, tidak sebanding dengan Angka Partisipasi Kasar (APK) perguruan tinggi di Indonesia. APK Indonesia hanya berada di kisarran 31,5\% sehingga membuat banyak PTS yang mempunyai mahasiswa kurang dari 500 dan ini membuat kondisi PTS tersebut tidak sehat. Dengan kondisi banyaknya PTS yang tidak sehat ini, tentunya menjadi tantangan bagi implementasi dari kebijakan "Merdeka Belajar Kampus Merdeka". Hal ini juga menuntut adanya komunikasi yang lebih baik dari pembuat kebijakan agar tujuan dari kebjakan ini dapat dilaksanakan oleh semua institusi yang berada di bawah 
pengawasan Kementerian Pendidikan dan Kebudayaan sebagai pembuat kebijakan "Merdeka Belajar Kampus Merdeka".

\section{Methods}

Artikel ini menggunakan pendekatan kualitatif. Data dikumpulkan melalui kajian Pustaka (literature review) berupa artikel, buku, dokumen, maupun pengamatan terhadap beberapa literatur atau sumber berita online yang memberitakan beberapa persepsi masyarakat maupun tokoh Pendidikan terhadap kebijakan "Merdeka Belajar, Kampus Merdeka". Langkah selanjutnya yang dilakukan adalah melakukan analisis dan menguraikan bahasan sesuai tema penelitian yang memiliki fokus pada efektivitas komunikasi kebijakan Merdeka Belajar, Kampus Merdeka yang diluncurkan oleh Kementerian Pendidikan dan Kebudayaan pada tanggal 24 Januari 2020.

Data utama dari penelitian ini adalah kebijakan Kementerian Pendidikan dan Kebudayaan tentang "Merdeka Belajar, Kampus Merdeka" dan respon serta persepsi dari perguruan tinggi, dosen dan mahasiswa sebagai pelaksana dari kebijakan ini. Data sekunder dari penelitian ini didapatkan dari artikel yang dipublikasikan baik pada jurnal nasional maupun internasional, undang-undang negara, serta sumber dari media daring (online) lainnya.

Nugroho (2012) cenderung menggunakan dua pendekatan dalam melakukan penelitian kebijakan, yaitu (1) pendekatan kelembagaan; dan (2) pendekatan aktor. Pendekatan kelembagaan memberikan fokus penelitian pada lembaga-lembaga yang dibuat oleh manusia. Dalam penelitian kebijakan yang menggunakan pendekatan kelembagaan, penelitian akan ditekankan pada muatan atau rumusan kebijakan, dan tentang proses kebijakan, yang berkenaan dengan proses keseluruhan dari suatu kebijakan.

Sedangkan pendekatan aktor memberikan fokus pada manusia-manusia pelaku. Pendekatan aktor merupakan paradigma yang meyakini bahwa para aktor-lah yang paling berperan dalam menentukan fakta-fakta sosial. Pendekatan tingkah laku yang lebih maju adalah pendekatan yang melihat pada nilai-nilai yang melatarbelakangi aktor-aktor tersebut.

Dalam menganalisas efektivitas komunikasi kebijakan "Merdeka Belajar, Kampus Merdeka", maka ada tiga aspek komunikasi yang efektif yang akan dianalisis yaitu: (1) Pesan dapat diterima dan dimengerti serta dipahami sebagaimana yang dimaksud oleh pengirimnya; (2) Pesan yang disampaikan oleh pengirim dapat disetujui oleh penerima dan ditindaklanjuti dengan pelaksanaan yang diinginkan oleh pengirim; (3) Tidak ada hambatan yang berarti untuk melakukan apa yang seharusnya dilakukan untuk menindaklanjuti pesan yang dikirim. Data primer dan sekunder yang dikumpulkan kemudian diidentifikasi untuk dinilai berdasarkan ketiga indikator tersebut (Moleong, 2002).

\section{Result and Discussion}

\subsection{Kebijakan "Merdeka Belajar, Kampus Merdeka"}

Empat kebijakan "Merdeka Belajar, Kampus Merdeka" yang dimaksud oleh Kemdikbud adalah:

(1) Mengubah Perguruan Tinggi Negeri (PTN) Satuan Kerja (Satker) menjadi sebuah PTN BH (Perguruan Tinggi Negeri dengan kekuatan Badan Hukum). Perubahan ini diharapkan agar PTN BH dapat lebih eluasa menjalin kemitraan dengan dunia industry dalam melakukan proyek komersil. Selain itu PTN BH dapat melakukan perubahan pada pengaturan keuangan dengan cepat sesuai dengan yang paling dibutuhkan.

(2) Adanya penyederhanaan pada akreditasi perguruan tinggi. Program re-akreditasi yang pada dasarnya bersifat otomatis untuk semua peringkat dan juga bersifat suakrela bagi perguruan tinggi. Akreditasi tetap berlaku lima tahun dan dapat diperbaharui secara otomatis. Akreditasi A akan diberikan pada perguruan tinggi yang berhasil mendapatkan akreditasi internasional.

(3) Membuka Program Studi (Prodi) baru. Kebijakan ini memberikan otonomi agi PTN maupun PTS untuk membuka atau mendirikan program studi yang baru. Otonomi ini diberikan jika PTN atau PTS telah memiliki akreditasi A ataupun B. 
(4) Adanya kegiatan dua semester diluar kampus. Kegiatan diluar kampus bisa dilakukan dengan magang atau praktik pada suatu organisasi.

Untuk dapat mengimplementasikan kebijakan ini maka pemerintah dalam hal ini Kemdikbud mengeluarkan lima kebijakan dalam bentuk Peraturan Menteri Pendidikan dan Kebudayaan (Permendikbud). Berdasarkan pernyataan yang disampaikan oleh Plt. Direktur Jenderal Pendidikan Tinggi dalam Siaran Pers Nomor: 020/Sipres/A6/II/2020, sebagaimana dilansir dari situs resmi Kemdikbud, ada empat kebijakan penting dalam Kampus Merdeka yaitu Pembukaan Program Studi Baru, Sistem Akreditasi Perguruan Tinggi, Perguruan Tinggi Badan Hukum dan Hak Belajar Tiga Semester di Luar Program Studi yang setiap kebijakannya memiliki payung hukum masing-masing. Kebijakan Pembukaan Program Studi Baru diatur dalam Permendikbud No.5 dan 7, Kebijakan Sistem Akreditasi Perguruan Tinggi diatur dalam Permendikbud No.5, Perguruan Tinggi Badan Hukum pada Permendikbud No. 4 dan 6 serta Hak Belajar Tiga Semester di Luar Program Studi dipayungi Permendikbud no.3. Lima Peraturan Mendikbud (Permendikbud) sebagai landasan penerapan Merdeka Belajar Kampus Merdeka yaitu Permendikbud No. 3 Tahun 2020 tentang Standar Nasional Pendidikan Tinggi, Permendikbud No. 4 Tahun 2020 tentang Perubahan Perguruan Tinggi Negeri menjadi Perguruan Tinggi Badan Hukum, Permendikbud No. 5 tahun 2020 tentang Akreditasi Program Studi dan Perguruan Tinggi, Permendikbud No.6 tahun 2020 tentang Penerimaan Mahasiswa Baru Program Sarjana pada Perguruan Tingggi Negeri dan Permendikbud No. 7 tentang Pendirian, Perubahan, Pembubaran Perguruan Tinggi Negeri dan Pendirian, Perubahan dan Pencabutan Izin Perguruan Tinggi Swasta (Biro Kerja Sama dan Hubungan Masyarakat Kementerian Pendidikan dan Kebudayaan, 2020).

\subsection{Kebijakan Publik dan Komunikasi Politik}

Kebijakan publik dapat diartikan sebagai kebijakan yang berhubungan dengan bidang yang didesain untuk kepentingan publik. Publik itu sendiri berisi aktivitas manusia yang dipandang perlu untuk diatur, atau diintervensi oleh pemerintah atau aturan sosial, atau setidaknya oleh tindakan bersama (Parsons, 2001:3). Kebijakan pubik pada umumnya mengandung pengertian tentang apa saja yang dipilih oleh pemerintah untuk dilakukan atau tidak dilakukan (Suharto, 2013). Kebijakan "Merdeka Belajar, Kampus Merdeka" merupakan sebuah kebijakan publik dalam bidang Pendidikan, yang merupakan sebuah terobosan dari Kemdikbud.

Hill (2005) menyatakan bahwa kebijakan dianggap sebagai milik pembuat kebijakan, yang kemudian diberi saran tentang cara implementasi yang lebih efektif yang melibatkan beragam versi. Kebijakan bukan hanya hal yang bersifat simbolis, tapi merupakan produk dari negosiasi dan kompromi. Oleh karena itu, seperti pendapat Barrett dan Hill (1981), banyak kebijakan mewakili kompromi antara nilai-nilai yang bertentangan, atau melibatkan kompromi dengan kepentingan utama dalam struktur implementasi, atau melibatkan kompromi dengan kepentingan-kepentingan utama yang memberi dampak pada implementasi, serta dibingkai tanpa memperhatikan kekuatan yang mendasarinya (terutama permasalahan ekonomi) yang dapat merusak esensinya (Hill, 2005).

Menurut Dunn (2012), analisis kebijakan diharapkan dapat menghasilkan informasi dan argument-argumen logis mengenai tiga jenis pertanyaan: (1) nilai yang pencapaiannya merupakan tolok ukur utama untuk melihat apakah masalah telah teratasi, (2) fakta yang keberadaannya dapat membatasi atau meningkatkan pencapaian nilai-nilai, dan (3) tindakan yang penerapannya dapat menghasilkan pencapaiaan nilai-nilai. Berdasarkan penelitian, keberhasilan sebuah kebijakan di negara maju, yang institusionalisasi masyarakatnya sudah mapan, berasal dari perumusan dan perencanaan kebijakan yang bagus. Sementara di negara-negara berkembang, di bawah konteks politik domestik, konflik laten, institusionalisasi politik yang tidak matang, keberhasilan kebijakan lebih bersandar pada sisi implementasi. Perumusan kebijakan berkontribusi sebesar 20\% dari total keberhasilan, sementara implementasi berkontribusi sebesar 60\% dan sisanya sebesar 20\% adalah kontribusi kontrol kebijakan (Nugroho, 2015).

Sebagai sebuah kebijakan yang dianggap baru, maka kebijakan ini berpotensi menimbulkan masalah (Winarno, 2012). Kebijakan ini cenderung sukar dilaksanakan dengan jumlah Angka Partisipasi Kasar (APK) hanya berada di kisaran 31,5\%, yang menunjukkan bahwa masih banyak jumlah PTS bermasalah yang memiliki jumlah mahasiswa kurang dari 500 orang. Sekalipun tujuan dari kebijakan ini sudah cukup jelas yaitu menciptakan kultur lembaga pendidikan yang otonom, tidak birokratis, dan terciptanya sistem pembelajaran yang inovatif berbasis pada peminatan dan tuntutan dunia modern, namun tidak semua perguruan tinggi dapat melaksanakan kebijakan ini. Hal ini juga diakui oleh Plt. Direktur Jenderal Pendidikan Tinggi Nizam dalam Siaran Pers Nomor: 020/Sipres/A6/II/2020 bahwa 
perguruan tinggi di Indonesia dengan jumlah lebih dari 4.500 kampus memiliki karakteristik berbeda dan juga memiliki tingkat kesiapan yang berbeda dalam menerapkan kebijakan Kampus Merdeka ini. Oleh karena itu, kebijakan Kampus Merdeka tidak akan bersifat paksaan yang akhirnya menjadi sekedar formalitas belaka (Biro Kerja Sama dan Hubungan Masyarakat Kementerian Pendidikan dan Kebudayaan, 2020). Staf yang tidak memadai serta kurangnya personil yang terampil dapat menjadi faktor penghambat untuk melaksanakan kebijakan ini. Hasil wawancara penulis dengan staf penyelenggara program Peningkatan Keterampilan Dasar Teknik Instruksional (Pekerti) yang bertujuan untuk meningkatkan kompetensi dosen sebagai SDM di perguruan tinggi, menunjukkan bahwa hanya sekitar $23 \%$ peserta program (seluruh peserta memiliki profesi sebagai dosen) yang mampu mengimplementasikan konsep merdeka belajar yang fokus pada Student Centered Learning (SCL) dalam rancangan desain kurikulum. Jika kondisi SDM sebagai salah satu pelaksana kebijakan tidak memadai, kemungkinan besar para pelaksana akan mengubah kebijakan baru untuk disesuaikan dengan SOP lama yang tidak tepat. Selain itu, alasan lain yang memperkuat hal ini, adalah minimnya informasi mengenai kebijakan "Merdeka Belajar, Kampus Merdeka" secara terperinci.

Komunikasi politik adalah proses interaktif tentang transmisi informasi antar politisi, media berita, dan publik. Proses komunikasi ini bisa berasal dari atas ke bawah, yaitu dari pemerintah kepada warga negaranya, secara horizontal dalam keterkaitan di antara para aktor politik, dan juga ke atas dari pendapat publik terhadap otoritas pemerintahan (Norris, 2001). Komunikasi politik tidak hanya mengikuti strategi tematik, tetapi juga strategi persuasi, seperti yang dijelaskan oleh Neidhardt (1994) "Pernyataan harus tampak benar, penjelasan harus tampak masuk akal, evaluasi harus tampak sah, dan tindakan harus tampak perlu dan menguntungkan" (Romy Froehlich, 2006).

Ada tiga faktor yang berpengaruh dalam proses komunikasi politik. Pertama, lingkungan fisik, yakni lingkungan tempat komunikasi itu berlangsung dengan menekankan pada aspek what dan how pesan-pesan komunikasi itu di pertukarkan. Kedua, situasi sosiokultural, yakni komunikasi merupakan bagian dari situasi sosial yang didalamnya terkandung makna kultural tertentu. Ketiga, hubungan sosial, yakni status hubungan antar pelaku komunikasi sangat berpengaruh, baik terhadap isi pesan itu sendiri maupun terhadap proses bagaimana pesan-pesan itu dikirim dan diterima (Tabroni, 2012).

Harold D. Lasswell, menekankan komunikasi politik pada pertanyaan who says what to whom via which channels with what effects? (Kaid, 2004). Pertanyaan ini dapat dipahami sebagai proses penyampain pesan politik dari pemberi pesan, disampaikan melalui media tertentu dan disampaikan pada siapa (penerima pesan) serta pengaruh apa yang ditimbukan dari pesan tersebut (Pawito, 2009). Adapun unsur-unsur komunikasi dapat dijabarkan sebagai berikut:

(1) Komunikator Politik, merupakan sumber atau komunikator politik. Dalam hal kebijakan "Merdeka Belajar, Kampus Merdeka", sumber/komunikator politiknya ada Kementerian Pendidikan dan Kebudayaan Republik Indonesia.

(2) Pesan Politik, yang disampaikan adalah kebijakan "Merdeka Belajar, Kampus Merdeka"

(3) Saluran atau Media Politik yang digunakan adalah media resmi pemerintah seperti situs resmi Kementerian Pendidikan dan Kebudayaan (Kemdikbud), media massa baik cetak maupun daring (online), serta saluran media lain yang banyak digunakan di masa pandemic covid 19 seperti zoom conference room yang biasanya berbentuk webinar, dan saluran media social lainnya.

(4) Sasaran atau Target Politik dari kebijakan ini adalah seluruh institusi perguruan tinggi beserta SDM yang ada di dalamnya yang biasa disebut sebagai civitas academica, juga perusahaan-perusahaan yang akan menjadi mitra dari perguruan tinggi.

(5) Pengaruh atau Efek Komunikasi Politik, adalah terciptanya pemahaman terhadap kebijakan "Merdeka Belajar, Kampus Merdeka (Cangara, 2016)

Norris (2001) menggambarkan model sistem proses komunikasi politik disajikan pada gambar 1. 


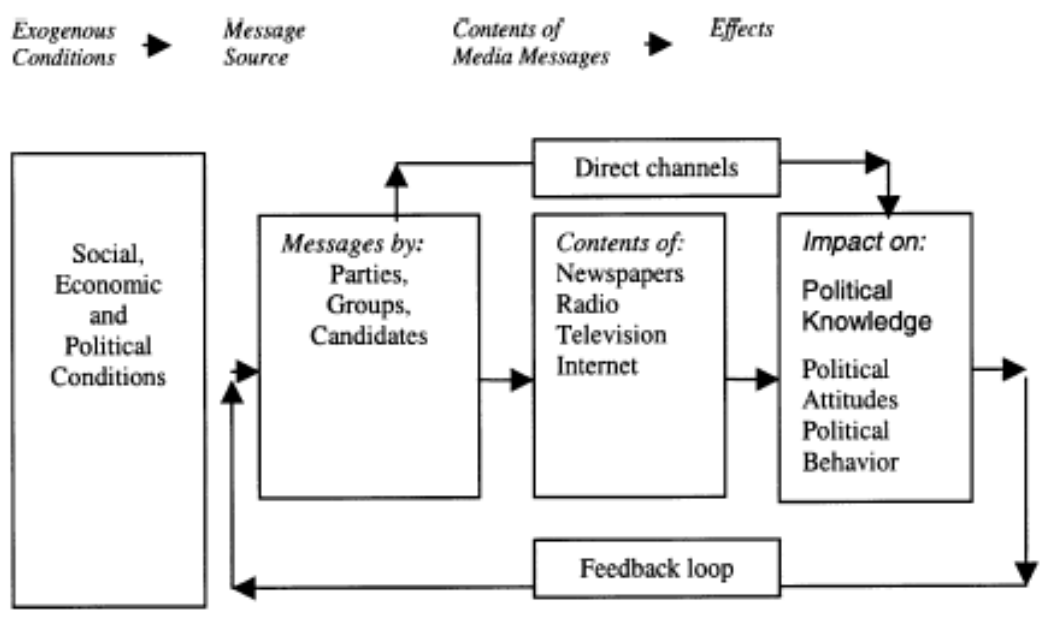

Fig. 1 Model sistem proses komunikasi politik

Sumber: Norris (2001)

Dari skema proses komunikasi politik diatas maka dapat dijelaskan bahwa sebuah kebijakan (messages/pesan) lahir dari kondisi sosial, ekonomi dan politik sebuah bangsa. Kemudian pesan (kebijakan) ini disampaikan bisa disampaikan secara langsung kepada penerima pesan atau dapat disampaikan melalui surat kabar, radio, televisi maupun internet. Adapun dampak yang diharapkan dari penyampaian pesan ini adalah adanya perubahan pada pengetahuan, sikap dan kebiasaan politik yang sesuai dengan tujuan isi dari pesan (kebijakan) yang disampaikan. Hal ini akan menjadi masukan (input) bagi penyempurnaan pesan (kebijakan) selanjutnya.

Oleh karenanya, untuk melihat apakah komunikasi politik terkait kebijakan "Merdeka Belajar, Kampus Merdeka" sudah effktif atau belum, maka diperlukan analisis pada media penyampaian pesan/kebijakan dan dampak dari pesan/kebijakan tersebut. Media penyampaian/sosialisasi kebijakan yang dipilih oleh Kemendikbud sudah dilakukan melalui empat media seperti yang disebutkan oleh Norris (2001). Ketika kebijakan ini disosialisasikan di awal setelah peluncuran (launching), ada beberapa tanggapan yang disampaikan para pengamat pendidikan di beberapa media nasional baik cetak maupun daring (online). Sebagian besar pengamat pendidikan menyatakan bahwa kebijakan ini akan sulit dilakukan terutama untuk program studi yang memang menuntut pemahaman secara teoritis seperti matematika, biologi, sosiologi dan ilmu politik. Hal ini disebabkan program studi tersebut mengarah pada pengembangan keilmuan bukan pengembangan keterampilan kerja. Dengan kebijakan membadanhukumkan PTN, hal ini akan memberikan keleluasaan bagi PTN yang berbadan hukum untuk menentukan besaran Uang Kuliah Tunggal (UKT). Konsekuensi dari kebijakan ini maka mahasiswa dari kelas bawah akan semakin sulit masuk ke PTN yang berbadan hukum. Selain itu, kebijakan ini juga dikhawatirkan akan membuat persaingan tidak sehat antar kampus dimana mahasiswa bebas belajar di kampus lain yang sudah bekerjasama dengan kampusnya. Maka kampus dengan kualitas yang kurang bagus akan tersingkir dengan persaingan ini (Fathurrohman, 2020). Sementara perguruan tinggi dengan kualitas bagus di Indonesia masih sangat sedikit jumlahnya.

Beberapa kritikan lain juga disampaikan setelah kebijakan ini diluncurkan oleh Kemendikbud. Pertama, potensi permasalahan dalam penangan administrasi mahasiswa yang berpindah dari satu prodi ke prodi lainnya, atau bahkan dari satu kampus ke kampus lainnya. Juga perbedaan standar penilaian antara satu perguruan tinggi dengan perguruan tinggi lainnya. Kedua, mahasiswa tidak bisa bebas memilih mata kuliah, karena harus ada pemahaman terhadap pengantar mata kuliah dalam suatu prodi. Ketiga, ada kekhawatiran kompetensi lulusan tidak spesifik keilmuannya. Sekalipun kritikan ini mendapat tanggapan bahwa beberapa kebijakan yang diluncurkan oleh Kemendikbud sudah ada bebeapa universitas yang melaksanakannya (Huriyah, 2020). Namun yang menjadi permasalahan adalah, berapa banyak perguruan tinggi yang sudah memiliki kemampuan untuk melaksanakan kebijakan ini?

Ada beberapa hal lain yang seharusnya menjadi bahan pertimbangan sebelum kebijakan ini dikeluarkan oleh Kemendikbud, seperti disampaikan oleh Hidayat Kampai (2020): 


\section{(1) Sistem Drop Out}

Berdasarkan data Kemenristekdikti (sekarang menjadi Kementerian Pendidikan dan Kebudayaan) pada tahun 2019 angka DO masih tinggi sekitar 8\% dari total mahasiswa tahun 2019 sebanyak 8.314.120 jumlah mahasiswa DO sebanyak 698.261 di bandingkan 2018 sebesar 3\%, Mahasiswa Drop Out terdiri dari mahasiswa dengan jenis Dikeluarkan, Putus Kuliah dan Mengundurkan Diri. DO ini merupakan gambaran belum adanya kebebasan dalam mengenyam pendidikan yang di jamin negara.

(2) Permudah syarat pendirian perguruan tinggi

Penyebaran perguran tinggi tidak merata ini menyebabkan banyak yang tak sanggup kuliah dikarena besarnya biaya lain selain biaya SPP. Saat ini jumlah perguruan tinggi yang ada di Indonesia sebanyak 4.621 dan masih berpusat di kota-kota besar yang ada di Pulau Jawa dan Sumatera.

Table 1. Jumlah Perguruan Tinggi di Indonesia

\begin{tabular}{cc}
\hline Kelompok Perguruan Tinggi & Tahun 2019 \\
\hline Universitas & 633 \\
Institut & 238 \\
Sekolah Tinggi & 2.501 \\
Akademi & 909 \\
Akademi Komunitas & 36 \\
Politeknik & 304 \\
Total Perguruan Tinggi & 4.621 \\
\hline
\end{tabular}

Sumber: Pangkalan Data Pendidikan Tinggi

(3) Penghapusan penjurusan di Sekolah Menengah Umum (SMU)

Penjurusan di SMU membuat anak-anak SMU mengalami benturan dalam memilih jurusan yang diinginkan di perguruan tinggi kecuali tidak ada ujian saringan masuk di perguruan tinggi yang sesuai dengan jurusan mereka.

Dari beberapa pendapat yang disampaikan terekam di media baik cetak maupun daring (online) menyiratkan bahwa masih ada pro dan kontra pendapat/opini terkait kebijakan "Merdeka Belajar, Kampus Merdeka". Hal ini menyiratkan bahwa pesan yang disampaikan oleh komunikator mendapatkan tanggapan yang berbeda-beda. Sebuah pesan akan dianggap efektif jika penerima pesan (komunikan) memahami isi pesan sesuai dengan yang diharapkan oleh pemberi pesan (komunikator). Efektivitas melihat adanya pemahaman bersama (mutual understanding) antara pengirim dan penerima pesan terhadap simbol-simbol yang di transmisikan (Syabrina, 2017). Kondisi sosial, ekonomi dan politik selama pandemi covid-19 juga mengalami perubahan yang cukup besar sehingga akan memberikan potensi masalah yang lebih besar bagi implementasi kebijakan ini di masa yang akan datang.

\section{Conclusion}

Komunikasi yang dilakukan oleh pemerintah dalam hal ini Kementerian Pendidikan dan Kebudayaan terkait kebijakan "Merdeka Belajar, Kampus Merdeka" belum efektif karena masih banyaknya kesalahan penafsiran pesan yang dimaksud oleh Kemendikbud dengan penafsiran pesan yang diterima oleh kalangan civitas akademika. Selain itu masih terdapat penolakan dari beberapa pengamat pendidikan dan juga perguruan tinggi yang merasa bahwa kebijakan ini belum siap untuk dilaksanakan dengan kondisi sebagian besar perguruan tinggi yang ada saat ini. Terakhir, sebagaimana yang disampaikan oleh Kemendikbud sendiri bahwa kebijakan ini hanyalah pilihan jika kondisi perguruan tinggi mampu untuk melaksanakannya. Hal ini menyiratkan bahwa implementasi kebijakan ini mengalami hambatan dan sulit untuk ditindaklanjuti. 


\section{References}

Antika, R. R. (2014). Proses Pembelajaran Berbasis Student Centered Learning (Studi Deskriptif di Sekolah Menengah Pertama Islam Baitul 'Izzah, Nganjuk. BioKultur, Vol.III/No.1/Januari-Juni , 251-263.

Biro Kerja Sama dan Hubungan Masyarakat Kementerian Pendidikan dan Kebudayaan. (2020, Februari 10). https://www.kemdikbud.go.id/main/blog/2020/02/kemendikbud-sosialisasikan-lima-permendikbud-sebagaipayung-hukum-kampus-merdeka. Retrieved from www.kemdikbud.go.id.

Cangara, H. (2016). Komunikasi Politik Konsep, Teori, dan Strategi. Depok: Raja Grafindo Persada.

Dunn, W. N. (2012). Pengantar Analisis Kebijakan Publik. Terjemahan Samodra Wibawa, Diah Asitadani, Agus Heruanto Hadna, Erwan Agus Purwanto. Yogyakarta: Gadjah Mada University Press.

Fathurrohman. (2020, Februari 10). https://fin.co.id/2020/02/10/kampus-merdeka-bakal-sulit-dilakukan/. Retrieved from https://fin.co.id: https://fin.co.id/2020/02/10/kampus-merdeka-bakal-sulit-dilakukan/

Hill, M. (2005). The Public Policy Process. Essex: Pearson Education Limited.

Huriyah, L. (2020, Februari 15). https://w3.uinsby.ac.id/kritik-terhadap-kritik-kampus-merdeka/. Retrieved from https://uinsby.ac.id: https://w3.uinsby.ac.id/kritik-terhadap-kritik-kampus-merdeka/

Kaid, L. L. (2004). Handbook of Political Communication Research. London: Lawrence Elbaum Associates.

Kampai, H. (2020, May 7). https://akuntansi.or.id/read-blog/5_kampus-merdeka-segenap-permasalahan-dantantangan-yang-harus-di-hadapi.html. Retrieved from https;//akuntansi.or.id: https://akuntansi.or.id/readblog/5_kampus-merdeka-segenap-permasalahan-dan-tantangan-yang-harus-di-hadapi.html

Moleong, L. J. (2002). Metodologi Penelitian Kualitatif. Remaja Rosda Karya.

Norris, P. (2001). Political Communication. International Encyclopedia of the Social \& Behavioral Sciences, 2nd edition, Volume 18, 11631-11640.

Nugroho, R. (2012). Public Policy. Jakarta: Elex Media Komputindo.

Nugroho, R. (2015). Kebijakan Publik di Negara-Negara Berkembang. Yogyakarta: Pustaka Pelajar.

Parsons, W. (2001). Public Policy Pengantar Teori dan Praktik Analisis Kebijakan. Terjemahan Tri Wibowo Budi Santoso. Jakarta: Kencana Prenadamedia Group.

Pawito. (2009). Komunikasi Politik Media Massa dan Kampanye Pemilihan. Yogyakarta: Jalasutra.

Romy Froehlich, B. R. (2006). Framing political public relations: Measuring success of political communication strategies in Germany. Public Relations Review 32, 18-25.

S, S. Y. (2018). Perubahan Sosial Budaya Masyarakat Indonesia dan Perkembangan Teknologi Komunikasi. Jurnal Al-Bayan Vol. 24 No. 1 , 29 - 46.

Suharto, E. (2013). Kebijakan Sosial Sebagai Kebijakan Publik. Bandung: Penerbit Alfabeta.

Syabrina, R. A. (2017). Efektivitas dan Efisiensi Komunikasi Pada Penyelenggaraan Festival Damar Kurung Gresik Tahun 2017. Surabaya: Fakultas Ilmu Sosial dan Ilmu Politik Universitas Airlangga Surabaya.

Syamsul Arifin, M. M. (2020). Tantangan Implementasi Kebijakan "Merdeka Belajar, Kampus Merdeka" Pada Perguruan Tinggi Islam Swasta di Indonesia. Jurnal Pendidikan UMS P-ISSN 2620-861X E-ISSN 26208628.

Tabroni, R. (2012). Komunikasi Politik Pada Era Multimedia. Bandung: Simbiosa Rekatama Media.

Winarno, B. (2012). Kebijakan Publik: Teori, Proses dan Studi Kasus. Yogyakarta: CAPS. 